\title{
Monitoring post-release behavioural activity of captive-bred urial (Ovis vignei punjabiensis) at Togh Managara Safari Park Khyber Pakhtunkhwa, Pakistan
}

\author{
Monitoramento da atividade comportamental pós-liberação de urial criado \\ em cativeiro (Ovis vignei punjabiensis) em Togh Managara Safari Park Khyber \\ Pakhtunkhwa, Paquistão

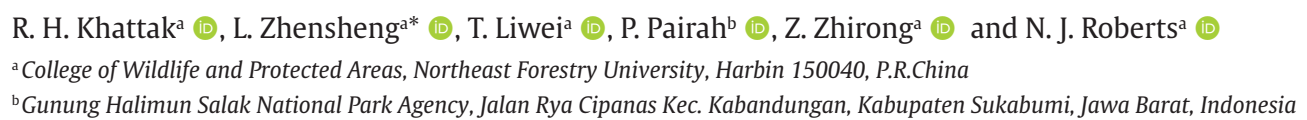

\begin{abstract}
The Punjab urial (Ovis vignei punjabiensis) is a globally threatened wild sheep species. In Pakistan the species is legally protected and bred in captivity to release into natural habitats to reinforce wild populations. Vigilance and feeding are critical to survival, though the degree to which captive-bred animals exhibit these behaviours post-release has rarely been investigated. We monitored the daily behaviours of five adult urial after release and classifying behaviours from $0600 \mathrm{hrs}$ to $1800 \mathrm{hrs}$, replicating each one-hour period twice and recording four observations of each animal per hour. At the herd level, vigilance and feeding behaviours were exhibited equally. Males and females invested equal time in feeding, males were more vigilant $(p=0.001)$ and more aggressive $(p=0.010)$, and females were more restful $(p=0.019)$ or engaged in grooming $(p=0.044)$ or locomotion ( $p=0.002$ ). Females spent more time feeding than being vigilant $(p=0.002)$. Males maintained high levels of vigilance throughout the day. Patterns of resting 1300 hrs to 1500 hrs and feeding in early morning and late afternoon were common for both sexes. Behaviours classified as 'other' were exhibited equally between sexes. Our results reveal positive indications of captive-bred urial balancing threat detection and energy acquisition post-release and exhibiting natural behaviours and activity patterns. We encourage assessment of survivorship to evaluate long-term effectiveness of captive breeding and release as a candidate restoration programme.
\end{abstract}

Keywords: animal behaviour, reintroduction, vigilance, feeding, large herbivore.

\begin{abstract}
Resumo
O Punjab urial (Ovis vignei punjabiensis) é uma espécie de ovelha selvagem ameaçada globalmente. No Paquistão, a espécie é legalmente protegida e criada em cativeiro para ser liberada em habitats para reforçar as populações selvagens. Vigilância e alimentação são essenciais para a sobrevivência, embora o grau de comportamento que os animais criados em cativeiro apresenta raramente tenha sido estudado. Cinco uriais adultos foram monitorados diariamente, após a liberação os comportamentos foram classificados das $6 \mathrm{~h}$ às $18 \mathrm{~h}$, replicando cada período de uma hora por duas vezes e registrando quatro observações de cada animal por hora. Em nível do rebanho, os comportamentos de vigilância e alimentação foram exibidos igualmente. Machos e fêmeas investiam tempo igual na alimentação, enquanto os machos eram mais vigilantes $(p=0,001)$ e mais agressivos $(p=0,010)$, as fêmeas eram mais repousantes $(p=0,019)$ ou mais engajadas no asseio $(p=0,044)$ ou na locomoção $(p=0,002)$. As fêmeas passam mais tempo se alimentando do que vigiando $(p=0,002)$. Os machos mantiveram altos níveis de vigilância ao longo do dia. Padrões de descanso de 1300 a 1500 horas e alimentação no início da manhã e no final da tarde eram comuns para ambos os sexos. Comportamentos classificados como "outros" foram exibidos igualmente entre os sexos. Os resultados revelam indicações positivas na detecção de ameaça em relação ao equilíbrio de criação urial em cativeiro e em aquisição de energia pósliberação, exibindo comportamentos naturais e padrões de atividade. Neste estudo, encorajou-se a utilização da avaliação de sobrevivência para avaliar a eficácia em longo prazo da reprodução em cativeiro e soltura como um programa de restauração dos candidatos.
\end{abstract}

Palavras-chave: comportamento animal, reintrodução, vigilância, alimentação, herbívoro de grande porte.

*e-mail: zhenshengliu@gmail.com; zhenshengliu@163.com

Received: September 05, 2020 - Accepted: November 16, 2020 


\section{Introduction}

During the last decades, populations of many wild species have drastically declined and face increased extinction risks (Woodroffe, 2001). This is also true for many wild animal species in Pakistan. Punjab urial (Ovis vignei punjabiensis) is a wild sheep that is globally declared as vulnerable with a decreasing population trend by the International Union for Conservation of Nature (Michel and Ghoddousi, 2020), and endangered in Pakistan (Sheikh and Molur, 2005). Urial are thus recognized as protected animals under Schedule 3 Section 22 of Khyber Pakhtunkhwa (KPK) Wildlife and Biodiversity Protection, Preservation, Conservation and Management Act, 2015.

Like many other endangered species for which captive breeding is co-ordinated as a conservation strategy, urial are reared in captivity in the north-western province of KPK, Pakistan (Khattak et al., 2020), with the goal to produce stable populations that can be eventually reintroduced into their natural habitats (Williams and Hoffman, 2009; Gusset and Dick, 2010). However, the restricted and confined environments of breeding facilities can limit behavioural performance of captive animals (Hakansson and Jensen, 2005; Mathews et al., 2005; Brereton and Rose, 2019). In general, animals raised in captivity are considered less fit for wild living in terms of lacking suitable skills and behaviours which are essential to survive successfully in the wild (Jule et al., 2008). Despite this perception, postrelease monitoring for many species has rarely been done (Clark et al., 2002; Beecham et al., 2015), and none to our knowledge in Pakistan.

Monitoring post-release behaviours is very useful to evaluate the animal's fitness, and providing a more complete insight into species ecology to further strengthen wildlife management practices (Myers and Young, 2018). Captivebred animals displaying proper post-release behaviours such as shelter seeking (Szor et al., 2008); optimal foraging (Owen-Smith et al., 2010); vigilance (Beauchamp, 2017); and anti-predator responses (Shier and Owings, 2006) can typically thrive successfully. Vigilance behaviour is very important to detect threats (Beauchamp, 2017); however in the case of ungulates, it may pose complex trade-off situations (Hunter and Skinner, 1998); resulting in reduced activity in other essential behaviours, namely foraging and resting (Beauchamp, 2007; 2012). Captive-bred animals can survive best after re-introduction if they are capable of balancing conflicting activities (Monus, 2018).

In captive breeding environments, wild animals live in close and regular contact with humans, which may cause habituation and compromise their natural fear response to different threats In such situations, along with natural threats of predators, poachers can be potentially lethal for the newly released captive-bred animals. Unfortunately, in Pakistan poaching is one of the major threats for wild ungulates (Shackleton, 2001; Baig and Al-Subaiee, 2009). Following (Monus, 2018) we assumed that reasonably levelling threat detection and resource acquisition increase survivorship of captive-bred urial in the natural habitat after release. Therefore, the current study was designed with the aim to evaluate post-release behavioural activity budgets and patterns of captive-bred urial in the wild habitat, with particular attention to vigilance and feeding. The results obtained from this study will provide benchmark data on post-release behaviours and activity patterns of captivebred urial, which can offer very promising insight for better management of captive stocks and the reinforcement and establishment of sustainable wild populations.

\section{Materials and Methods}

\subsection{Study area}

The current study was conducted in Togh Managara Safari Park (TMSP) (33 31' 42.7224" N, 71 30' 14.6376" E) in Kohat district, KPK province. This park encompasses an area of 3000 acres (1214.057 ha). The area harbours sub-tropical evergreen forests with rocky hillocks terrain, providing ideal habitat for wild ungulates. The dominant trees include Acacia modesta (Phulai), Acacia nilotica (Kikar), Montheca buxifolia (Gwargurah), Zizyphus mauratiana (Ber) and Eucalyptus camaldulensis (Laachi). The park is rich in shrubs and grasses as well, including Dodonea viscosa (Ghwarsky), Zizyphus nummularia (Karkara), Adhatoda viscosa (Baza), Rhazya stricta (Gandeer), Sccharum munja (Kana), Cynodon dactylon (Kabbal), Cenchrus ciliaris (Dhaman), Cymbopogon jawarancus (Spin wakha) and Themeda anathera (Mita gass). Notable mammal species at TMSP include Ovis vignei (urial), Gazella bennettii (chinkara), Felis chaus (jungle cat), Canis aureus (jackal), Vulpes vulpes (red fox), Lepus nigricollis (Indian hare) and Hystrix indica (porcupine). Annual mean temperature of TMSP varies between $22.8-24.4^{\circ} \mathrm{C}$.

\subsection{Study animals}

A herd of five captive-bred urial ( $n=5$ [ 2 male; 3 female], mean age $=1.86 \pm 0.18$ years) were released at TMSP on July 27, 2019. We consider these animals to be adults (Geist, 1968 ) and were born in a breeding facility (40 m x $40 \mathrm{~m}$ ) located at TMSP. Human-urial interaction at this facility is low, typically no more than daily interaction with animal care staff twice daily during feeding and routine duties, one veterinarian visit per month, and occasional visitors.

\subsection{Behavioural observations}

Following Schaller and Mirza (1974) and Khattak et al. (2019) we designed an ethogram. Group scan sampling (Martin et al., 1993) was used to record urial post-release behaviours daily from August 01 - 30, 2019, from 0600 hrs to 1800 hrs. Animals were not followed for the first three days after release in order to allow them to settle. After locating the herd in the morning, to reduce any effect of our own disturbance on animal behaviour, we tried to observe them from a hidden spot. Binoculars (10x40, Nikon Monarch ATB 7345, Japan) were used to aid observations. All animals remained as a single herd for the duration of the study period.

We classified activity patterns into seven categories: Vigilance, Feeding, Resting, Aggression, Grooming, 
Locomotion and Others. Vigilance included all those events when an animal was standing watchful, scanning for any threat and displaying an alert posture. Sudden fleeing after alert posture was also included as vigilance, recording as a new bout. Feeding included foraging, searching for food, ruminating and drinking. Resting included all those events when an animal was found lying still, lying with eyes closed or standing still without any alertness. Aggression included direct head and horns strikes, pushing one another back (head-to-head or horns), chasing, blocking, kicking, strong butting and thrusting vegetation. Grooming included either an animal licking itself of any other animal, gently scratching, and rubbing itself or any other animal of the herd. Locomotion included walking and running without any signs of fear. Others included urinating, defecating, playing, sniffing, sexual behaviours and flehmen response. Additional field notes were also recorded, including forage species.

\subsection{Statistical analysis}

The percentage of each behaviour was calculated for respective analyses. Mann Whitney U-test was used to measure the differences between male and female activities and also the differences between feeding and vigilance behaviours. Data were analyzed using SPSS version 16.0 (SPSS Inc., Chicago, IL, USA). Significance level was set at 0.05 .

\section{Results}

The results obtained in the current study showed that male and female urial had different activity patterns (Table 1). Males spent most of their time in vigilance behaviours followed by feeding, others, resting, aggression, locomotion and grooming, while females spent most of their time feeding followed by locomotion, resting, others, vigilance, grooming and aggression. Male urial spent significantly more time engaged in vigilance behaviours than females $(Z=-3.393 ; p=0.001)$, and also aggression behaviours $(Z=-2.576 ; p=0.010)$. Females spent significanly more time resting than males $(Z=-2.343 ; p=0.019)$, and also in locomotion behaviours $(Z=-3.064 ; p=0.002)$ and grooming $(Z=-2.012 ; p=0.044)$. There were no significant differences in feeding $(Z=-0.688 ; p=0.492)$ and behaviours grouped as 'others' $(Z=-1.135 ; p=0.256)$.

Considering the temporal spread of activity budgets between 0600 hrs and 1800 hrs,-males were observed as being highly vigilant throughout the day, feeding in the morning (0600 hrs - $1100 \mathrm{hrs}$ ) and late afternoon (1700 hrs $-1800 \mathrm{hrs}$ ), while resting during the period 1300 hrs - 1500 hrs (Figure 1). Female urial dedicated most of their time to feeding in the morning (0600 hrs $1100 \mathrm{hrs}$ ), midday (1200 hrs $-1300 \mathrm{hrs}$ ) and in the later part of the day (1500 hrs - 1800 hrs; Figure 2). In the afternoon (1300 hrs - $1500 \mathrm{hrs}$ ), they spent most of their time resting. There were no significant differences between frequency of daily feeding and vigilance behaviours collectively within the herd, though females spend less time being vigilant than feeding (Table 2). Moreover we found that both male and female urial preferred foraging on Zizyphus nummularia, Zizyphus mauratiana, Acacia modesta, Cymbopogon jawarancus and Themeda anathera.

\section{Discussion}

Post-release monitoring of captive-bred animals is very important to determine the success of this stage of breeding and reintroduction programs and check whether the released population has successfully established itself or not. However, such studies should ideally be conducted over long periods and are no doubt very costly (Batson et al., 2015). Keeping in view our reasonable budget constraints, we investigated the post-release activity patterns of urial in TMSP for one month. Although our sample size was relatively small, the results obtained are of key importance in wildlife management especially for captive-bred stock, as it is likely to be the first post-release monitoring of any captive-bred ungulate species in Pakistan. Collecting data of wild-born animals for comparison was not realistic due to their low occurrence probability as a threatened species and logistical constraints of research. Consequently, the results are discussed in relation with published literature only.

Table 1. Post-release behavioural activities of captive-bred urial, presented as percentage of all behaviours.

\begin{tabular}{lccc}
\hline \multirow{2}{*}{ Behaviour } & \multicolumn{2}{c}{ Proportion of behaviour $($ mean \pm SE) } & Statistical difference \\
\cline { 2 - 3 } & Male & Female & \\
\hline Vigilance & $29.69 \pm 2.78$ & $11.80 \pm 1.55$ & $\mathrm{Z}=-3.393 ; p=0.001^{*}$ \\
Feeding & $22.92 \pm 2.23$ & $25.00 \pm 2.23$ & $\mathrm{Z}=-0.688 ; p=0.492$ \\
Resting & $8.86 \pm 1.46$ & $17.36 \pm 2.71$ & $\mathrm{Z}=-2.343 ; p=0.019^{*}$ \\
Aggression & $7.81 \pm 1.84$ & $1.74 \pm 0.73$ & $\mathrm{Z}=-2.576 ; p=0.010^{*}$ \\
Grooming & $1.56 \pm 0.76$ & $4.86 \pm 1.55$ & $\mathrm{Z}=-2.012 ; p=0.044^{*}$ \\
Locomotion & $7.29 \pm 1.72$ & $21.53 \pm 2.86$ & $\mathrm{Z}=-3.064 ; p=0.002^{*}$ \\
Others & $21.88 \pm 2.58$ & $17.71 \pm 1.17$ & $\mathrm{Z}=-1.135 ; p=0.256$ \\
\hline
\end{tabular}

$*$ Statistical significance. 
Vigilance is a key behavior especially in prey species to avoid predation and other threats (Pulliam, 1973; Benoist et al., 2013). Our results revealed that these captive-bred urial displayed more or less similar activities like vigilance, foraging and others budgets with wild-born urial (Ayaz et al., 2012). We found that despite being raised in captivity and in close association with humans, these animals still retained their vigilant nature (Schaller and
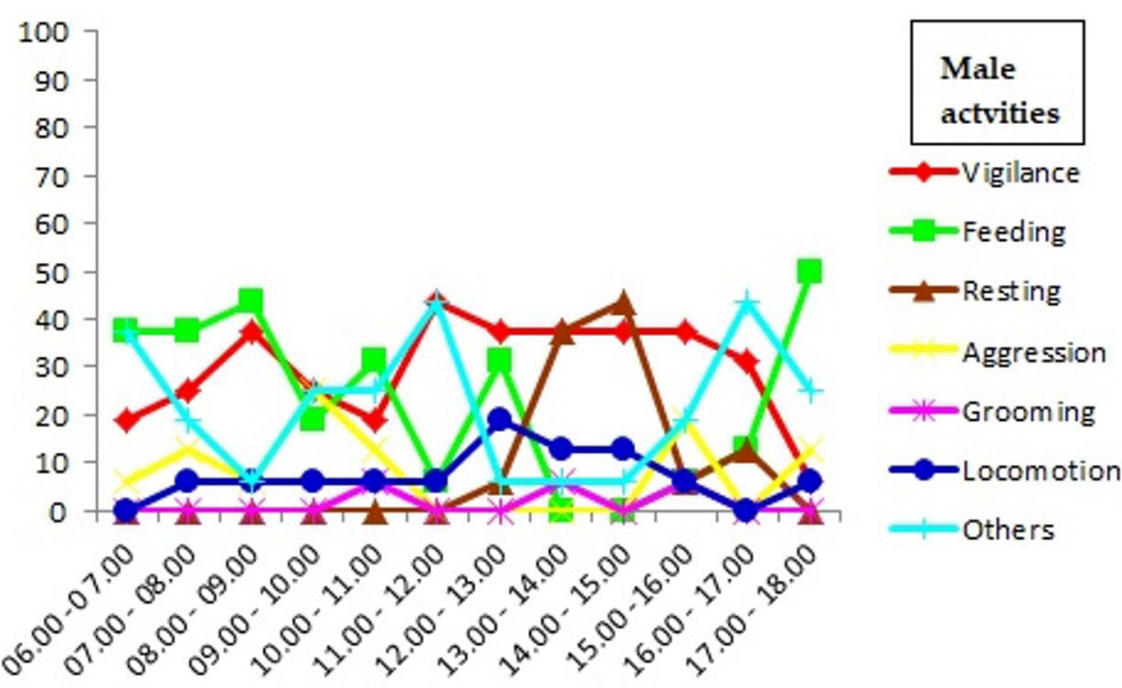

Figure 1. Time budget of male's activities.

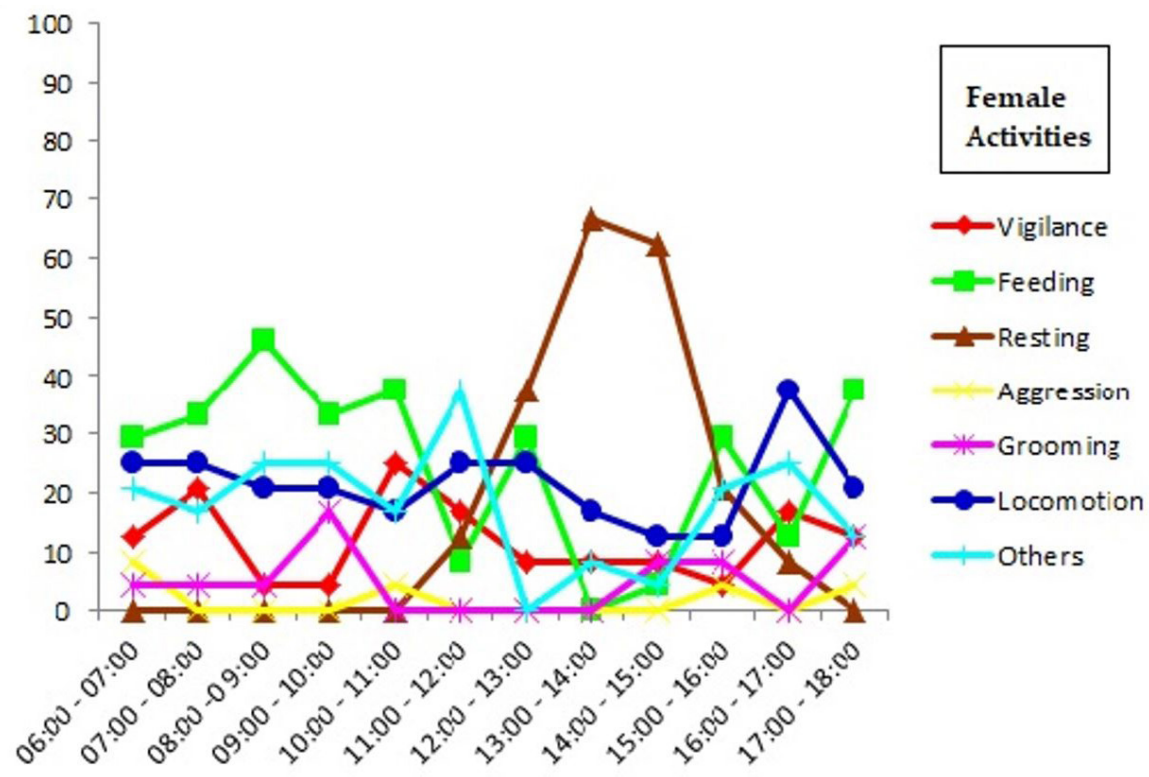

Figure 2. Time budget of female's activities.

Table 2. Collective activity budgets of feeding and vigilance behaviours for both sexes.

\begin{tabular}{cccc}
\hline \multirow{2}{*}{ Sex } & \multicolumn{2}{c}{ Proportion of activity (mean $\pm \mathbf{S E}$ ) } & \multirow{2}{*}{ Statistical difference } \\
\cline { 2 - 3 } & Feeding & Vigilance & \\
\hline Male + Female & $23.96 \pm 1.54$ & $20.75 \pm 2.77$ & $-1.136 ; p=0.256$ \\
Male & $22.92 \pm 2.23$ & $29.69 \pm 2.78$ & $\mathrm{Z}=-1.708 ; p=0.088$ \\
Female & $25.00 \pm 2.23$ & $11.80 \pm 1.55$ & $\mathrm{Z}=-3.075 ; p=0.002^{\circ}$ \\
\hline
\end{tabular}

\footnotetext{
$*$ = Statistical significance.
} 
Mirza, 1974; Ayaz et al., 2012). Compared with females, males were significantly more vigilant, supporting the recognized variation in vigilance levels among ungulate species (Pecorella et al., 2019). Urial are gregarious ungulates (Khattak, et al., 2019) in which males are usually more vigilant (Schaller and Mirza, 1974) detecting threats, mates and competing males. Females typically become more vigilant when they have offspring, which are more vulnerable to predation and other threats (Childress and Lung, 2003; Hamel and cote, 2007). Thus, we attributed the comparatively low vigilance of females in our study to being without offspring; yet the herd displayed a likely favourable level of vigilance and anti-predator behaviours, balanced alongside other behaviours.

Moreover, males of wild sheep become extraordinarily vigilant once they experience human disturbance (Benoist et al., 2013). Although we made considerable effort to reduce our own observer effect on animal behaviour, due to the species living in mobile herds and going out of sight we had to change our position, causing vigilance and running behaviours. Despite typically higher humanurial encounters in captivity and suspected likelihood of habituation, the observed results are encouraging as the animals remain alert post-release. We note that these animals had no pre-release training, human-urial interaction was limited in captivity, and behavioural monitoring began just three days after release.

In our study we found that the females and males spent equal time feeding. However, adult males have higher metabolic rates and typically need less time for feeding (Van Soest and Demment, 1985; Xu et al., 2012) and females reportedly take advantage of male vigilance and reduce their own to increase energy acquisition (Rieucau and Martin, 2008). In natural wild habitats, gregarious ungulates usually take advantage of vigilance by the conspecifics living in the same group and tend to maintain a constant balance between vigilance and feeding (Illius and Fitzgibbon, 1994). Keeping in view the gregarious nature of urial and collective results of vigilance and feeding obtained from the current study, the herd level result (males and females combined) strongly suggests that these captive-bred animals seem capable to maintain a constant equilibrium between threat detection and resource acquisition, though females maintain equal investment in feeding as males but reduce their vigilance within the herd.

Captivity forces animals to adjust their behaviour in response to the altered environments and schedules. Such altered behaviours can pass to next generations and may compromise both the ex-situ and in-situ conservation efforts for endangered species (McPhee and Carlstead, 2010); thus to maintain the natural behaviours in captivity is of key importance. In our study we found that both male and female urial were observed feeding in the early morning and late afternoon hours of the day, while mostly resting in the early to mid afternoon. Wild sheep in natural habitats exhibit these same activity patterns (Schaller and Mirza, 1974; Liu et al., 2005). Post-release foraging patterns by these urial were exactly similar to the wild-born urial, including selected forage species (Schaller and Mirza, 1974; Ayaz et al., 2012; Khattak et al., 2019). Based on these results we strongly suggest that captive-bred urial are capable of retaining their intrinsic behaviors postrelease into wild environments.

We found that males were more aggressive than females. Among wild social ungulates, adult males are comparatively more aggressive (McClelland, 1991; Pecorella et al., 2019). Most of the agonistic events took place between males, mainly head-to-head strikes and chasing each other. Males did however, display aggression towards females as well. Urial are polygynous ungulates (Ralfs Wildlife and Wild Places, 2019) and thus the higher aggression levels of males can be attributed to mating and establishing social dominance (Emlen and Oring, 1977; CluttonBrock et al., 1979; Appleby, 1980; Weckerly et al., 2001). We observed no specific aggression from females towards males, yet very few female-to-female aggressive events were observed, mainly head-butts. Similar findings have been reported for female European Mouflon sheep (Ovis orientalis musimon) (McClelland, 1991) which closely resemble urial having similar ecological niches. Moreover, low vigilance levels among the females in our observation group can likely also be attributed to study period, as it was conducted before the rut season. Normally, females in gregarious ungulate species show higher aggression levels when they are conceiving (Thompson, 1993).

We found that the newly released captive-bred urial displayed good locomotion skills, and that females were more mobile compared with males. In gregarious ungulates, while foraging, females usually move faster than the males (Weckerly et al., 2001). Moreover, we found that compared with males, females mostly preferred to forage on the elevated and rocky parts of the release site. Such post-release behaviors displayed by urial are remarkably similar to the strategies adopted by wild mountain sheep (Ovis canadensis nelsoni), in which females prefer to use the most rugged terrain in order to minimize predation risk (Bleich et al., 1997). Captive-bred animals are more prone to lack proper locomotion skills after re-introduction, as well as skills finding food, seeking shelter and detecting threats (Stoinski and Beck, 2004). Our findings however, suggest that captive-bred urial after release display satisfactory locomotion skills, moving across the landscape throughout the study period, and we thus assume that they are capable to spatially orient themselves and adequately find resources.

Both sexes dedicated time to grooming, with higher levels among females. Grooming was mostly observed in the early hours of the day. Similar results have been reported for Javan deer (Rusa timorensis) (Pairah et al., 2014). Grooming is mostly performed for reducing the burden of ticks and also to avoid insects which may cause pathogenic infection (Akinyi et al., 2013; Zhukovskaya et al., 2013). Both sexes performed other behaviors equally.

\section{Conclusion}

The results obtained in the current study provide insight into the post-release activities of captive-bred urial. Based on these results, newly released urial seem capable of quickly adapting to wild environments. Post- 
release activity patterns shown by the urial favour our hypothesis of levelling post-release threat detection and resource acquisition for successful adaption, as they are maintaining acceptable balance between contrasting activities, especially vigilance and feeding behaviours. To develop post-release monitoring, we recommend long-term studies regarding home range and habitat use by using modern GPS-telemetry tools, and to monitor survival, mortality and disease infestation rates as pressing conservation needs. Strict restrictions over unnecessary human interactions with captive stock, as experienced by the study animals pre-release, has been shown to be very promising for favourable post-release adaptation with new wild habitats. We believe that captive breeding of urial is an advisable practice for the restoration of this species back into its ancestral distribution range throughout Pakistan.

\section{Acknowledgements}

This study was supported by the National Nature Science Foundation of China (31870512), and the fundamental research funds for the central universities (2572014CA03). This study also got financial support from Heilongjiang Touyan innovation team program for forest ecology and conservation, Ningxia Helan Mountains National Nature Reserve. We are grateful to the Khyber Pakhtunkhwa Wildlife Department, Pakistan for allowing us to carry our study. We would like to extend special thanks to Kohat Wildlife Division for their tremendous cooperation throughout the study.

\section{References}

AKINYI, M.Y., TUNG, J., JENEBY, M., PATEL, N.B., ALTMANN, J. and ALBERTS, S.C., 2013. Role of grooming in reducing tick load in wild baboons (Papio cynocephalus). Animal Behaviour, vol. 85, no. 3, pp. 559-568. http://dx.doi.org/10.1016/j.anbehav.2012.12.012. PMid:24659824.

APPLEBY, M.C., 1980. Social rank and food access in red deer stags. Behaviour, vol. 74, no. 3-4, pp. 294-309. http://dx.doi. org/10.1163/156853980X00519.

AYAZ, S.M., JAMIL, A.A., KHAN, M. and AYAZ QAMAR, M.F., 2012. Behaviour and biology of Ovis orientalis (urial) in Kotal Wildlife Park and Borraka Wildlife sanctuary in Kohat.Journal of Animal and Plant Sciences, vol. 22, pp. 29-31.

BAIG, M.B. and AL-SUBAIEE, F.S., 2009. Biodiversity in Pakistan: key issues. Biodiversity (Nepean), vol. 10, no., 4, pp. 20-29. http:// dx.doi.org/10.1080/14888386.2009.9712858.

BATSON, W.G., GORDON, I.J., FLETCHER, D.B. and MANNING, A.D., 2015. Translocation tactics: A framework to support the IUCN guidelines for wildlife translocations and improve the quality of applied methods. Journal of Applied Ecology, vol. 52, no. 6, pp. 1598-1607. http://dx.doi.org/10.1111/1365-2664.12498.

BEAUCHAMP, G., 2007. Competition in foraging flocks of migrating semipalmated sandpipers. Oecologia, vol. 154, no., 2, pp. 403-409. http://dx.doi.org/10.1007/s00442-007-0818-8. PMid:17676344.

BEAUCHAMP, G., 2012. Foraging speed in staging flocks of semipalmated sandpipers: Evidence for scramble competition. Oecologia, vol. 169, no. 4, pp. 975-980. http://dx.doi.org/10.1007/ s00442-012-2269-0. PMid:22302514.

BEAUCHAMP, G., 2017. What can vigilance tell us about fear? Animal Sentience, vol. 2, no. 15, pp. 1. http://dx.doi.org/10.51291/23777478.1203 .
BEECHAM, J.J., DE GABRIEL HERNANDO, M., KARAMANLIDIS, A.A., BEAUSOLEIL, R.A., BURGUESS, K., JEONG, D.H., BINKS, M., BERECZKY, L., ASHRAF, N.V.K., SKRIPOVA, K., RHODIN, L., AUGER, J. and LEE, B.-K., 2015. Management implications for releasing orphaned, captive-reared bears back to the wild. The Journal of Wildlife Management, vol. 79, no., 8, pp. 1327-1336. http://dx.doi.org/10.1002/jwmg.941.

BENOIST, S., GAREL, M., CUGNASSE, J.M. and BLANCHARD, P., 2013. Human disturbances, habitat characteristics and social environment generate sex-specific responses in vigilance of Mediterranean mouflon. PLoS One, vol. 8, no. 12, pp. e82960. http://dx.doi.org/10.1371/journal.pone.0082960. PMid:24386131.

BLEICH, V.C., BOWYER, R.T. and WWHAUSEN, J.D., 1997. Sexual segregation in mountain sheep: resources or predation? Wildlife Monographs, vol. 134, pp. 3-50.

BRERETON, J.E. and ROSE, P.E. 2019. Comparing the behaviour of wild and captive flamingos: An evaluation of published data on time-activity budgets. Flamingo, vol. 1, pp. 34-49.

CHILDRESS, M.J. and LUNG, M.A., 2003. Predation risk, gender and the group size effect: does elk vigilance depend upon the behaviour of conspecifics? Animal Behaviour, vol. 66, no. 2, pp. 389-398. http://dx.doi.org/10.1006/anbe.2003.2217.

CLARK, J.D., HUBER, D. and SERVHEEN, C., 2002. Bear reintroductions: lessons and challenges. Ursus, vol. 13, pp. 335-345.

CLUTTON-BROCK, T.H., ALBON, S.D., GIBSON, R.M. and GUINNESS, F.E., 1979. The logical stag: adaptive aspects of fighting in red deer (Cervus elaphus L.). Animal Behaviour, vol. 27, pp. 211-225. http://dx.doi.org/10.1016/0003-3472(79)90141-6.

EMLEN, S.T. and ORING, L.W., 1977. Ecology, sexual selection, and the evolution of mating systems. Science, vol. 197, no. 4300, pp. 215-223. http://dx.doi.org/10.1126/science.327542. PMid:327542.

GEIST, V., 1968. On delayed social and physical maturation in Mountain Sheep. Canadian Journal of Zoology, vol. 46, no. 5, pp. 899-904. http://dx.doi.org/10.1139/z68-126. PMid:5749649.

GUSSET, M. and DICK, G., 2010. Building a Future for Wildlife? Evaluating the contribution of the world zoo and aquarium community to in situ conservation. International Zoo Yearbook, vol. 44, no. 1, pp. 183-191. http://dx.doi.org/10.1111/j.1748-1090.2009.00101.x.

HAKANSSON, J. and JENSEN, P., 2005. Behavioural and morphological variation between captive populations of red junglefoul (Gallus gallus) - Possible implications for conservation. Biological Conservation, vol. 122, no. 3, pp. 431-439. http://dx.doi. org/10.1016/j.biocon.2004.09.004.

HAMEL, S. and CÔTÉ, S.D., 2007. Habitat use patterns in relation to escape terrain: Are alpine ungulate females trading off better foraging sites for safety? Canadian Journal of Zoology, vol. 85, no. 9, pp. 933-943. http://dx.doi.org/10.1139/Z07-080.

HUNTER, L.T.B. and SKINNER, J.D., 1998. Vigilance behaviour in African ungulates: The role of predation pressure. Behaviour, vol. 35, no. 2, pp. 195-211.

ILLIUS, A.W. and FITZGIBBON, C., 1994. Costs of vigilance in foraging ungulates. Animal Behaviour, vol. 47, no. 2, pp. 481-484. http:// dx.doi.org/10.1006/anbe.1994.1067.

JULE, K.R., LEAVER, L.A. and LEA, S.E., 2008. The effects of captive experience on reintroduction survival in carnivores: a review and analysis. Biological Conservation, vol. 141, no. 2, pp. 355-363. http://dx.doi.org/10.1016/j.biocon.2007.11.007.

KHATTAK, R.H., LIU, Z. and TENG, L., 2019. Development and Implementation of Baseline Welfare Assessment Protocol for Captive Breeding of Wild Ungulate: Punjab Urial (Ovis vignei 
punjabiensis, Lydekker 1913). Animals, vol. 9, no. 12, pp. 1102. http://dx.doi.org/10.3390/ani9121102. PMid:31835388.

KHATTAK, R.H., LIU, Z., TENG, L. and ROBERTS, N.J., 2020. Determining optimal stock density of Punjab Urial (Ovis vignei punjabiensis) in captivity for breeding, population growth and reintroduction potential. Pakistan Journal of Biological Sciences, vol. 23, no. 9, pp. 1127-1230. PMid:32981254.

LIU, Z.S., WANG, X.M., LI, Z.G., CUI, D.Y. and LI, X.Q., 2005. Seasonal variation of diurnal activity budgets by blue sheep (Pseudois nayaur) with different age sex classes in Helan Mountain. Zoological Research, vol. 26, no. 4, pp. 350-357. PMid:25017757.

MARTIN, P., BATESON, P.P.G. and BATESON, P., 1993. Measuring behaviour: An introductory guide. Cambridge: Cambridge University Press. http://dx.doi.org/10.1017/СBO9781139168342.

MATHEWS, F., ORROS, M., MCLARENL, G., GELLING, M. and FOSTER, R., 2005. Keeping fit on the ark - Assessing the suitability of captive-bred animals for release. Biological Conservation, vol. 121, no. 4, pp. 569-577. http://dx.doi.org/10.1016/j. biocon.2004.06.007.

MCCLELLAND, B.E., 1991. Courtship and agonistic behavior in mouflon sheep. Applied Animal Behaviour Science, vol. 29, no. 1-4, pp. 67-85. http://dx.doi.org/10.1016/0168-1591(91)90238-S.

MCPHEE, M.E. and CARLSTEAD, K., 2010. The importance of maintaining natural behaviors in captive mammals. In: D. KLEIMAN, K. THOMPSON and K. BAER, eds. Wild mammals in captivity: Principles and techniques for zoo management. Chicago: University of Chicago Press, vol. 2, pp. 303-313.

MICHEL, S. and GHODDOUSI, A., 2020 [viewed 9 August 2020] Ovis vignei. The IUCN Red List of Threatened Species. Available from: https://dx.doi.org/10.2305/IUCN.UK.2020.2.RLTS. T54940655A54940728.en

MONUS, F., 2018. Competing activities as measures of fear and vigilance. Animal Sentience, vol. 2, no. 15, pp. 8. http://dx.doi. org/10.51291/2377-7478.1312.

MYERS, P.J. and YOUNG, J.K., 2018. Post-release activity and habitat selection of rehabilitated black bears. Human-Wildlife Interactions, vol. 12, no. 3, pp. 322-337.

OWEN-SMITH, N., FRYXELL, J.M. and MERRILL, E.H., 2010. Foraging theory upscaled: the behavioural ecology of herbivore movement. Philosophical Transactions of the Royal Society B. Biological Science, vol. 365, no. 1550, pp. 2267-2278. http:// dx.doi.org/10.1098/rstb.2010.0095.

PAIRAH., SANTOSA, Y., PRASETYO, L.B. and MUSTARI, A.H., 2014. The time budget of Javan Deer (Rusa timorensis, Blainville 1822) in Panaitan Island, Ujung Kulon National Park, Banten, Indonesia. Hayati Journal of Biosciences, vol. 21, no. 3, pp. 121-126. http:// dx.doi.org/10.4308/hjb.21.3.121.

PECORELLA, I., FATTORINI, N., MACCHI, E. and FERRETTI, F., 2019. Sex/age differences in foraging, vigilance and alertness in a social herbivore. Acta Ethologica, vol. 22, no. 1, pp. 1-8. http:// dx.doi.org/10.1007/s10211-018-0300-0.

PULLIAM, H.R., 1973. On the advantages of flocking. Journal of Theoretical Biology, vol. 38, no. 2, pp. 419-422. http://dx.doi. org/10.1016/0022-5193(73)90184-7. PMid:4734745.

RALFS WILDLIFE AND WILD PLACES, 2019 [viewed 13 July 2020]. Punjab Urial (Ovis vignei punjabiensis) [online]. Available from: https://www.wilddocu.de/punjab-urial-ovis-vigneipunjabiensis/

RIEUCAU, G. and MARTIN, J., 2008. Many eyes or many ewes: vigilance tactics in female bighorn sheep Ovis canadensis vary according to reproductive status. Oikos, vol. 117, no. 4, pp. 501-506. http://dx.doi.org/10.1111/j.0030-1299.2008.16274.x.

SCHALLER, G.B. and MIRZA, Z., 1974. On the behaviour of Punjab urial (Ovis orientalis punjabiensis). In: V. GEIST and F. WALTHER. The behaviour of ungulates and its relation to management. Calgary, Canada: The University of Calgary, pp. 306-323.

SHACKLETON, D.M., 2001. A review of community-based trophy hunting programs in Pakistan. IUCN.

SHEIKH, K. and MOLUR, S. 2005. Status and Red List of Pakistan Mammals, based on conservation assessment and management plan for mammals. Islamabad, Pakistan: International Union for Conservation of Nature and Natural Resources. 344 p.

SHIER, D.M. and OWINGS, D.H., 2006. Effects of predator training on behavior and post-release survival of captive prairie dogs (Cynomys ludovicianus). Biological Conservation, vol. 132, no. 1, pp. 126-135. http://dx.doi.org/10.1016/j.biocon.2006.03.020.

STOINSKI, T.S. and BECK, B.B., 2004. Changes in locomotor and foraging skills in captive- born, reintroduced golden lion tamarins (Leontopithecus rosalia rosalia). American Journal of Primatology, vol. 62, no. 1, pp. 1-13. http://dx.doi.org/10.1002/ ajp.20002. PMid:14752809.

SZOR, G., BERTEAUX, D. and GAUTHIER, G., 2008. Finding the right home: distribution of food resources and terrain characteristics influence selection of denning sites and reproductive dens in arctic foxes. Polar Biology, vol. 31, no. 3, pp. 351-362. http:// dx.doi.org/10.1007/s00300-007-0364-1.

THOMPSON, K.V., 1993. Aggressive behavior and dominance hierarchies in female sable antelope, Hippotragus niger: implications for captive management. Zoo Biology, vol. 12, no. 2, pp. 189-202. http://dx.doi.org/10.1002/zoo.1430120205.

VAN SOEST, P.J. and DEMMENT, M.W., 1985. A nutritional explanation for body-size patterns of ruminant and non-ruminant herbivores. American Naturalist, vol. 125, no. 5, pp. 641-672. http://dx.doi.org/10.1086/284369.

WECKERLY, F.W., MCFARLAND, K., RICCA, M.A. and MEYER, K.P., 2001. Sexual segregation in Roosevelt elk: cropping rates and aggression in mixed-sex groups. Journal of Mammalogy, vol. 82, no. 3, pp. 825-835. http://dx.doi.org/10.1644/15451542(2001)082<0825:SSIREC>2.0.CO;2.

WILLIAMS, S.E. and HOFFMAN, E.A., 2009. Minimizing genetic adaptation in captive breeding programs: A review. Biological Conservation, vol. 142, no. 11, pp. 2388-2400. http://dx.doi. org/10.1016/j.biocon.2009.05.034.

WOODROFFE, R., 2001. Strategies for carnivore conservation: lessons from contemporary extinctions. In: Carnivore conservation. Cambridge: Cambridge University Press, pp. 61-92.

XU, F., MA, M., WU, Y.and YANG, W., 2012. Winter daytime activity budgets of Asiatic ibex Capra sibirica in Tomur National Nature Reserve of Xinjiang, China. Pakistan Journal of Zoology, vol. 44, no. 2, pp. 389-392.

ZHUKOVSKAYA, M., YANAGAWA, A. and FORSCHLER, B.T., 2013. Grooming behavior as a mechanism of insect disease defense. Insects, vol. 4, no. 4, pp. 609-630. http://dx.doi.org/10.3390/ insects4040609. PMid:26462526. 